\title{
ANALYSIS OF MORTGAGE LENDING IN BANKS IN UKRAINE
}

\author{
Violetta KHARABARA ${ }^{1}$ \\ Yuriy Fedkovych Chernivtsi National University, Ukraine
}

\begin{abstract}
The purpose is a mortgage market that occupies one of the major places among the financial mechanisms of economic stimulation and stable development of the economy. The mortgage market occupies one of the main places of financial mechanisms and economic incentives for the sustainable economic development. Mortgage lending covers the provision of long-term bank loans for the purchase, construction of residential real estate, as well as for repairs or to develop their own small businesses, where the collateral for such loans is real estate. Distinctive features of mortgages include: mortgages, like any collateral, in fact, is a way to ensure proper implementation of the other (main) liabilities - loan or credit agreement, lease, contract, compensation, etc.; the subject of a mortgage is always real estate. Real estate includes land plots and everything that is firmly associated with them: buildings, perennial plants, etc.; mortgaged property remains in the possession of the debtor; the agreement between the creditor and the debtor on the establishment of a mortgage is formalized by a special document - the mortgage, which is also subject to state registration. The mortgage crediting is the method of accumulation of financial resources, effective instrument of bank activity, and an important factor in economic development of the country on the whole. Research results are market of the real estate and financial services development, to the revival of fund market, here the mortgage crediting is capable not only of activating reforms in industries of the economy but also gradually providing the decision of housing problems of the population. Practical consequences consist in the solution of problems that are related to the market for mortgage services of Ukraine's development from 2006 to 2016. Value/originality. Analysis of the mortgage market in Ukraine shows that in recent years, its scope, dynamics, and trends do not meet the needs of either people or developers. At a time when the dynamics of macroeconomic indicators do not give hope for a quick exit from the crisis and high political risks increase the uncertainty of social development, long-term mortgage loans are risky for the banking sector and for borrowers. Implementation methods in combination with the continuation of market reforms in Ukraine will contribute to the economic growth and socio-economic development.
\end{abstract}

Key words: mortgage, mortgage lending, mortgage market, loan portfolio, mortgage refinancing.

JEL Classification: G10, G21

\section{Introduction}

The mortgage market occupies one of the most important places among financial mechanisms of economic incentives and steady economic development. Mortgage lending is a method of accumulating financial resources, an effective tool for banking activity, and an important factor for the economic development of the county in general. Promoting real estate development and financial services, recovery of the stock market, mortgage lending can not only activate reforms in the economy but also gradually ensure solving housing problems of the population. The use of this tool will significantly reduce tension in the housing sector by providing an average citizen the opportunity to acquire housing through a mortgage.

However, despite its relevance, mortgage lending in Ukraine has still not received a proper development.
The share of mortgage in Ukraine's GDP is less than $1 \%$, while for the countries of the average level of development the World Bank has set this indicator at the level of $25 \%$ of GDP. Throughout the EU, the figure is estimated to be over 52\%, in the US - more than $76 \%$.

Problems associated with mortgage lending have been studied by many economists, including: B. Busov, O. Hudz, M. Demianenko, O.T. Yevtukh, O.O. Yevtukh, S. Kruchok, V. Lahutin, A. Somyk, A. Chupis, K. Palyvoda, B. Hnatkivskyi, I. Liutyi, O. Berehulia, L. Labetska, O. Kireev, I. Kovalyshyn, G. Andreeva.

A wide range of different theoretical and methodological aspects of mortgage are reflected in the works of national scientists: M. Haienko, N. Hryshchuk, V. Kravchenko, V. Krylova, O. Nepochatenko, I. Puchkovska, V. Savych, S. Yurhelevych.

The work is devoted to the study of the essence of the category of mortgage lending, as well as the analysis of

Corresponding author:

${ }^{1}$ Department of Finance and Credit, Yuriy Fedkovych Chernivtsi National University.

E-mail: viola.17@ukr.net 
the current state of the housing market in Ukraine. The institutional component of the mortgage loan market is assessed and the main problems and prospects of development of this sphere of economic relations in the state are considered.

\section{Methodical approaches}

Real estate has always been appreciated in banking as a reliable guarantee of repayment. Pledge of land and real estate for a long-term credit is called a mortgage. The mortgage is a kind of pledge of real estate (land, enterprises, buildings, structures, and other objects directly connected with the ground) in order to borrow money. In the case of non-payment of loans, the pledged property is sold, and amount of proceeds pays off the debt to the creditor.

According to the Law of Ukraine "On Mortgage", mortgage is defined type of security of the fulfilment of the obligations by real estate that is owned and used by the mortgagor, under which the mortgagee has the right in case of nonfeasance by the debtor of the obligation secured by mortgage to get his claims covered by the object of mortgage mainly before other creditors of the debtor in the manner established by this law.

Mortgage lending is crediting on a pledge of real estate loans or crediting using mortgages as security for the repayment of credit.

On the basis of analysis of the economic literature aimed at studying the nature and characteristics of the mortgage, its following features can be identified:

- mortgage is used as a tool for raising funds for the development of production;

- mortgage ensures the implementation of property rights to object ownership when implementing other forms of ownership (e.g. sale) is inappropriate in a particular situation;

- mortgage contributes to the creation of fictitious capital through the possibility of issuing securities, leading to the increase in collateral working capital by the value of created fictitious capital.

In economic terms, the mortgage is a market instrument of implementation of property rights for real estate objects in cases where other forms of alienation (sale, exchange) legally or financially are inexpedient that allows raising additional funds for various projects.

In Ukraine, mortgage lending is regulated by a number of regulations, laws of Ukraine "On the National Bank of Ukraine", "On Banks and Banking Activity", "On Investment Activity", "On Financial and Credit Mechanisms and Management of Property at Housing Construction and Real Estate Transactions", "On Restoring Debtor's Solvency or Declaring It Bankrupt”, "On Mortgage", "On Pledge", as well as by Housing, Civil and Land Codes, and more.

Although the concept of "mortgage" and "mortgage lending" in the national and foreign literature is thoroughly researched and widely used in practice, the study of theoretical and practical aspects of mortgage housing is omitted. Furthermore, some scientists have questioned the existence of this type of loan, namely mortgage construction loan, determining mortgage and construction loans as a "completely different types of credit". While other scientists attribute credit for the construction using a mortgage as collateral for the borrowed funds to the mortgage.

National Bank of Ukraine interprets residential mortgage loan as a long-term loan provided by individuals, partnerships owners of apartments or housing cooperatives for financing costs associated with the construction or purchase of an apartment or dwelling house (including land under this apartment building or infield), which are provided in the property of lender by the borrower's acceptance of such housing (land under it, or infield) in bail. Thus, the National Bank of Ukraine refers mortgage construction loan to housing mortgage credit.

\section{Research results}

The state of the mortgage market is significantly affected by trends in real estate market, in particular, by that part of the market, where a supply and demand are formed for real estate, which can be used as collateral for mortgage lending. Mortgage lending has an influence on the growth of investment in construction. Proof of this is the dynamics of capital investment through bank loans and other loans.

Showed that bank loans as a source of investment capital make up about $12-15 \%$, and their volume unevenly fluctuated over the period. The largest share of bank loans was observed in $2008-15.8 \%$, and the lowest in $2015-7.3 \%$, and since 2008 there is the gradual decline in the share of bank loans in financing capital investments.

It should be noted that the mechanisms of construction financing through mortgages exist in many countries. Banks lend to both end-users - citizens, and producers builders. This is due to the fact that mortgage lending to construction is very effectively combined with classical mortgage lending to individuals - buyers. Obtained loans and own funds of citizens are used to pay the cost of purchased apartments, and the developer is able to repay the earlier loan.

The main macroeconomic factors of the depressed mortgage market are the sharp deterioration of the banking system, in particular, the fall in loans to the economy, the rising cost of deposits falling of bank capital, income, and GDP. Since one of the main indicators of economic development is the growth rate of GDP and its volume, then an assessment of the level of mortgage lending is expedient in terms of mortgage portfolio related to GDP. 
In 2006 in Ukraine, the share of mortgage loans to GDP was $1.9 \%$, in $2012-7.9 \%$, by the end of 2015 $6.1 \%$, characterizing the Ukrainian mortgage market as underdeveloped. Instead, the volume of mortgage loans in the US and in the EU is almost 50\% of GDP, in the UK $-60 \%$, in the Netherlands and Denmark $70 \%$. This is due to the fact that conditions for mortgage lending in these countries are very favourable: interest rates on mortgages in these countries are 3.5-3.75\%, which is comparable to the rate of price increases, and practically zero real interest rates mortgage makes it extremely attractive.

During the 2013-2016 years in Ukraine, the state of mortgage lending is characterized by decreased growth rates of loans, rising interest rates, a reduction in the term loans and the number of banks offering mortgages. Because of too high interest rates, Ukraine has very significant potential demand for housing, which is sensitive both to changes in house prices and financing terms. Bank claims to customers are rather rigid: the presence of official income sufficient to repay the loan, a good credit history.

According to statistics from the National Bank of Ukraine, during 2007, there were fluctuations in the value of mortgage loans: loans in national currency increased - by 12 percentage points (p.p.) compared to 2006, while loans in USD and EUR fell by 10.8 p.p. and 1.8 p.p. respectively.

In 2008 compared to the previous 2007, mortgage loans in the national currency have been decreased 7.3 p.p. and loans in US dollars increased - 7.7 p.p., for loans in Euro, significant changes have not occurred. During 2009-2012, a gradual increase in mortgage loans in local currency can be observed and a simultaneous decrease in the US dollars. Already in 2013, their share in total mortgage loans was almost equal and amounted to $47.1 \%$ - in local currency and 47.1 - in US dollars. During 2014-2015, the situation has changed, so that the loans in national currency decreased at the end of 2015 , and amounted to $37.1 \%$, and in US dollars, on the contrary, increased and amounted to 59.4\%; loans in Euro have not undergone substantial changes and remained at a low level $-2.55 \%$ of total mortgage loans.

Analysing the dynamics of mortgage loans for 20112015 , it can be concluded that the leading position in terms of the total volume of loans and, consequently, income for the period 2011-2015 among the analysed banks is taken by PJSC "Privatbank" and PJSC "Oschadbank". Regarding the indicator of a share of loans secured by real estate in the total volume of loans, there is a slightly different situation. In particular, the leaders on this indicator are PJSC "Ukrsotsbank", PJSC "KredoBank" (Table 1).

Demand for housing remains limited, the effect of temporary factors that supported it is especially confined in Kyiv. Loans for housing intensified but the amounts are too small to influence the market or create risks. The shift in the amount of supply can be attributed to changes in its structure by region, housing options offered for sale and terms of financing its purchase. Prices for residential real estate in the capital in dollar terms are reduced but growing at a slower pace, the number of transactions is low but slowly growing. Commercial real estate today is unattractive for investment.

Demand for housing remains is limited. The real income of the population has barely grown significantly in the II quarter of 2016 after a significant drop in the result of a prolonged crisis. This is one of the first signs of early growth of purchasing power, which, however, is not enough to significantly increase the demand for

Table 1

Dynamics of mortgage loans for the period of 2011-2015 (million UAH)

\begin{tabular}{|c|c|c|c|c|c|}
\hline \multirow[b]{2}{*}{ Indexes } & \multirow[b]{2}{*}{ Years } & \multicolumn{4}{|c|}{ Banks } \\
\hline & & $\begin{array}{c}\text { Private Joint } \\
\text { Stock Company } \\
\text { "Oschadbank" }\end{array}$ & $\begin{array}{c}\text { Private Joint Stock } \\
\text { Company } \\
\text { "PrivatBank" }\end{array}$ & $\begin{array}{c}\text { Private Joint } \\
\text { Stock Company } \\
\text { "Ukrsotsbank" }\end{array}$ & $\begin{array}{c}\text { Private Joint } \\
\text { Stock Company } \\
\text { "KredoBank" }\end{array}$ \\
\hline \multirow{5}{*}{$\begin{array}{l}\text { Total number of } \\
\text { loans }\end{array}$} & 2011 & 50459 & 107755 & 29471 & 2084 \\
\hline & 2012 & 51337 & 123452 & 25400 & 2450 \\
\hline & 2013 & 52179 & 139663 & 28061 & 2698 \\
\hline & 2014 & 70236 & 161830 & 32630 & 3691 \\
\hline & 2015 & 65462 & 189147 & 36403 & 4248 \\
\hline \multirow{5}{*}{$\begin{array}{l}\text { Number of loans } \\
\text { secured by real estate }\end{array}$} & 2011 & 15398 & 62195 & 21184 & 1362 \\
\hline & 2012 & 19897 & 11834 & 18172 & 1430 \\
\hline & 2013 & 24750 & 7339 & 21614 & 1326 \\
\hline & 2014 & 29762 & - & 23996 & 1711 \\
\hline & 2015 & - & - & 24400 & 2140 \\
\hline \multirow{5}{*}{$\begin{array}{l}\text { Share of loans } \\
\text { secured by real estate } \\
\text { In the total number } \\
\text { of loans }\end{array}$} & 2011 & 30,5 & 9,93 & 64,9 & 65,3 \\
\hline & 2012 & 38,7 & 9,6 & 71,4 & 58,4 \\
\hline & 2013 & 47,4 & 5,25 & 77,02 & 49,2 \\
\hline & 2014 & 42,4 & - & 73,5 & 46,3 \\
\hline & 2015 & - & - & 67,0 & 50,4 \\
\hline
\end{tabular}


residential real estate. Therefore, it is determined by the factors, which under normal circumstances are secondary. First, the risk of losing deposits in insolvent banks forcing investors to withdraw money and buy housing. The impact of this factor is gradually eroding, due to the cleaning of the banking sector is coming to an end, the sustainable inflow of deposits indicates a slow recovery of confidence in the banks. Second, the abrupt fall of hryvnia allows those accumulated before the crisis currency savings to find attractive price offers in housing and use them. The influence of these factors also decreased as a result of a stabilization in the currency market and depletion of savings. Third, the demand from settlers from the occupied territories is almost fully implemented.

In addition to home buyers, banks lend to developers. This applies both to the capital and to regions. Large companies take loans for up to three years. Smaller companies obtain short-term loans from banks and use them to maintain the pace of construction if newly built apartments cannot be sold quickly. However, total lending by developers is currently small. The main source of funding is the developers' own funds and proceeds from buyers.

In the face of declining inflation and interest rates, further growth of hryvnia mortgage banks and financing of developers can be expected. However, in the short term, its rate will moderate in view of the shortage of quality borrowers and the unresolved problem of foreign currency debt. Given that today the scale of such lending is small, its growth will not create risks and so will not have a significant impact on housing prices. In the long term, to control risks creating housing market for financial stability, the National Bank intends to carefully monitor the prices and start a systematic calculation of LTV indicator (LOAN-TO-VALUE RATIO) for mortgage loans.

\section{Findings}

The analysis of the mortgage market in Ukraine shows that in recent years, its scope, dynamics, and trends do not meet the needs of either people or developers. At a time when the dynamics of macroeconomic indicators do not give hope for a quick exit from the crisis and high political risks increase the uncertainty of social development, long-term mortgage loans are risky for the banking sector and borrowers.

For the development of mortgage housing, in our opinion, there is a need for government assistance through:

- completing the legal framework for mortgage lending;

- stability of hryvnia;

- favourable development programs of a partial compensation of property value;

- creating competition between banks in the domestic market, which increases the attractiveness of the mortgage;

- activation of state involvement in mortgage lending; - creation of favourable conditions for attracting financial resources in mortgage lending;

- lowering interest rates and increasing lending in accordance with international standards.

The implementation of the above together with the continuation of market reforms in Ukraine will contribute to the economic growth and socio-economic development.

\section{References:}

Belikov, T. (2014). Current state and prospects of development of mortgage lending in Ukraine. Scientific Journal "Business Inform, 7: 304-308.

Lyubun, A. (2011). Mortgages, 1: 392.

Sarmatytska, O. (2013). Bulletin of the National Technical University "KhPI", 20 (993): 146-154.

Storozhenko, O. (2014). Financial mechanism mortgage. Bulletin ONU, 1 (2): 141-145.

Yakushev A.M. (2006). Development funding mechanism construction of Housing: Abstract Dis. candidate. ekon. Sciences specials. 08.00.10:240.

\section{Виолетта ХАРАБАРА}

\section{АНАЛИЗ ИПОТЕЧНОГО КРЕДИТОВАНИЯ В БАНКАХ УКРАИНЫ}

Аннотация. Цель работы. Ипотечный рынок, который занимает одно из главных мест среди финансовых механизмов экономического стимулирования и устойчивого развития экономики. Ипотечное жилищное кредитование охватывает предоставление долгосрочных банковских кредитов на приобретение, строительство жилой недвижимости, а также на проведение ремонтных работ или на развитие собственного малого бизнеса, где залогом по такому кредиту является недвижимое имущество. Отличительными чертами ипотеки являются: ипотека, как и всякий залог, по сути, является способом обеспечения надлежащего исполнения другого (основного) обязательства - займа или кредитного договора, договора аренды, подряда, возмещения вреда и тому подобное; предметом ипотеки всегда является недвижимость. К недвижимому имуществу относятся земельные участки и все, что прочно с ними связано: здания, сооружения, многолетние 
Vol. 3, No. 3, 2017

насаждения и т.д.; предмет ипотеки остается во владении должника; договор кредитора и должника об установлении ипотеки оформляется специальным документом-закладной, которая также подлежит государственной регистрации. Метод. Ипотечное кредитование - метод накопления финансовых ресурсов, эффективного инструмента банковской деятельности и важного фактора экономического развития страны в целом. Исследовательские результаты. Рынок недвижимого имущества и финансового развития услуг, к возрождению рынка фонда, здесь ипотечное кредитование способно не только, чтобы активизировать реформы в промышленности экономики, но и постепенно, чтобы обеспечить решение жилищных проблем населения. Практические последствия заключаются в решении проблем, что связаны с рынком ипотечных услуг украинского развития с 2006 до 2016. Оригинальность значения. Анализ развития ипотечного рынка в Украинесвидетельствует, чтовпоследнеевремяегообъемы,динамикаитенденции развитиянеудовлетворяли потребности ни населения, ни застройщиков. В условиях, когда динамика макроэкономических показателей не дает надежды на быстрый выход из кризиса, а высокие политические риски повышают неопределенность развития общества, долгосрочное ипотечное кредитование является рискованным как для банковского сектора, так и для заемщиков. Реализация методов в комплексе с продолжением рыночных реформ в Украине будут способствовать экономическому росту и социально-экономическом развитии. 